DOI: $10.2478 /$ auseur-2019-0010

\title{
National Minority: The Emergence of the Concept in the Habsburg and International Legal Thought ${ }^{1}$
}

\author{
Anna ADORJÁNI \\ Universität Wien \\ e-mail: anna.adorjani@univie.ac.at \\ László Bence BARI \\ Central European University \\ e-mail: bari_bence@phd.ceu.edu
}

\begin{abstract}
This paper critically analyses how the term 'minority' was conceptualized in the Habsburg and international political and legal thought from the nineteenth century until the Minority Treaties after the First World War. We argue that the phrase 'national minority' was absent from the legal language up to 1918. Our paper guides the reader through the various traditions and their interwar interpretations that shaped the emergence of the new concept of 'minority'. The analysis of parliamentary discourses within the Habsburg Empire shows how old and new meanings coexisted in 1918.
\end{abstract}

Keywords: national minority, Late Habsburg Monarchy, nationality question, minority rights, conceptual history

\section{Introduction}

The problem that ethno-cultural boundaries do not match territorialadministrative units is not new. This issue is often referred to as 'minority problem,' where 'national' was generally implied when using the word 'minority'. Unless stated otherwise, in this article, we are talking about 'minority' in reference to nationality. Yet, the term 'minority' was rarely used to talk about ethnic groups

1 This research received funding from the European Research Council (ERC) under the European Union's Horizon 2020 research and innovation programme under Grant Agreement No 758015. It was partially supported by the Domus Hungary Scholarship of the Hungarian Academy of Sciences and the Ernst Mach Grant. We thank our colleagues from the ERC Project 'NonTerritorial Autonomy as Minority Protection in Europe' at the University of Vienna, Department of East European History, who provided insight and expertise that greatly assisted the research. 
before 1918 (Viefhaus 1960: VII). The claim to equal rights and liberties for members of an ethno-cultural group is considered as one of the most important questions of the nineteenth century. Yet, these problems were rarely referred to as the 'minority question'. ${ }^{2}$ In the nineteenth century, the issue of mismatch between ethnic groups and imperial state territory was referred to as the 'nationality question'.

Later on, in the interwar period, a new discipline of minority studies emerged, which started anachronistically referring to the 'nationality question' as 'minority protection'. Interwar scholars wrote a new history of 'international minority protection' as a teleological evolution which started from the Peace of Westphalia (1648) and unfolded in the creation of the League of Nations (1919). We understand by 'anachronistic terms' the analytical categories that the historian uses to domesticate or translate ideas of the past to the audience of his time, notwithstanding that the authors of old texts did not apply those categories when elaborating the ideas in question (Burke 2007: 7-10, Skinner 1969: 3-53). In this paper, we use the term 'legal category' to refer to the term as used in the Minority Treaties. The term 'political category' refers to the earlier relational-quantitative meaning of the word 'minority'. The phrase 'analytical category' refers to the meta-term used by scholarship.

Our paper looks into the historicity of the concept in the Austrian and Hungarian part of the Habsburg Monarchy. With the close reading of primary sources, our paper offers a critical analysis of the historical conceptualization of the term 'national minority'. Firstly, we will look into the ideological continuities and discontinuities of the concept. We will present which domestic and international intellectual views shaped the idea of minority and re-defined its meaning between the seventeenth century and 1918. Afterwards, we will freeze the moment when 'minority' emerged as an international legal concept during the First World War and made its way to the Habsburg context - roughly the year of 1918.

Reviewing the interwar literature on minority rights written by scholars both from the successor states of the Habsburg Empire and those of the Allies, we identified two recurring ideological traditions that shaped the intellectual area in which the new legal, political, and analytical term of minority emerged. The first is the tradition of the European international peace treaties that we will elaborate in the first part of our paper. The narrative of the international history of minority protection presented peace treaties as the first documents of 'international minority protection'. In these peace treaties, the great powers recognized territorial conquest and newly established states. The condition of such recognition was to

2 In 1852, Hungarian liberal thinker Lajos Kossuth formulates this problem as the 'language question': 'In Europe, the language question is now brought to the fore, and liberty will suffer greatly for a long time. This is misfortunate. Nonetheless, we got the question. Now it is time to find the solution' (Kónyi 1889: 33-34). This citation and the following ones were translated into English by the author. 
confer rights to various religious, linguistic, and ethnic groups inside the new borders. Our aim was to call attention to the absence of the word 'minority' in the text of the peace treaties and thus think critically about the subject and purpose of the 'minority provisions' before and after the First World War. The interwar tradition often neglected that the purpose of the peace treaties was not to solve the 'nationality question' but rather to protect the power balance in a monarchic spirit.

The second tradition that shaped the new minority concept was the 'nationality question' as raised in the European multinational empires. We started our research by looking at the early appearances of the term 'national minority' in the Habsburg context. When we analysed and contextualized the Austrian and Hungarian legal and political texts from the second half of the nineteenth century, we found out that the terms 'national' and 'minority' hardly ever appeared in a joint phrase. To provide examples of how nineteenth-century politicians and thinkers expressed the idea of 'national minorities', we will offer a variety of nineteenth-century synonyms of what we now call 'national minority'. With the ambition to show the substantial differences between the tradition of 'protecting subjects' and that of the 'nationality question', we sectioned out these two traditions that interwar literature often merged as the single story of 'minority protection'.

One of the most challenging aspects of our inquiry is the relation between modern democratic principles and the new concept of minority. Political thinkers of the nineteenth century already reflected on the inextricable dilemma between historical administrative structures and the modern concept of nation. In multinational empires, the principle of the equality of all nations or nationalities was at complete odds with the principle of majority in exercising power on a given territory. Yet, in the second half of the nineteenth century, minority and majority was most commonly used in the parliamentary context, and the dilemma was referred to as the 'nationality question'. Consequently, the parliamentary term of minority/majority itself had to democratize, i.e. refer to all individuals of a state to make its way in the international legal language.

To illustrate both the co-existence and the differences between the two traditions in 1918, we analysed the Hungarian and Austrian parliamentary debates and their political language when the legal concept of minority emerged. Starting from the evidence Viefhaus provided in his book on the genesis of the Minority Treaties at the Paris Peace Conference (Viefhaus 1960: VII), we argue that the notion of 'national minority' is organically linked to that of the nationstate. Therefore, we can consider 1918 the moment when the legal concept of 'national minority' took shape parallel to the planned nationalization of the imperial state territory. As opposed to the previous conception of minority, the new term meant not only a temporary, proportional relation but a permanent state of inferiority. Accordingly, the new term of '(national) minority' referred not only to a quantitative but also to a qualitative inferiority. 


\section{The International History of Protecting National Minorities: The Roots of a Narrative}

In the interwar times, the implementation of the Minority Treaties brought to the fore two critical problems: firstly, who are the minorities (who is the subject of the rights) and, secondly, what is the question that the Minority Treaties give an answer to (the purpose of conferring rights)? Legal specialists and sociologists dedicated themselves to these theoretical and practical questions with an analytical and scholarly interest. Along with specialists from the former Habsburg Monarchy, such as Ignaz Seipel, Arthur Balogh, Oscar Jászi, and Imre Mikó, French and British scholars, such as Fouques Duparc and Carlile Aylmer Macartney, ${ }^{3}$ investigated the very subject of their discipline: the concept of minority and the origins of minority rights. Based on a selection of historical precedents, a narrative of continuous history of minority protection became mainstream. This narrative saw 'minority rights' everywhere since the interventions on behalf of the Christian populations in the Ottoman Empire starting from the sixteenth century up until the Minority Treaties in 1919. ${ }^{4}$ This train of thought might seem coherent, yet it is historically incorrect.

In the following quotation from 1934, British academic Macartney both exemplifies and explains the appeal of the narrative of continuity and the anachronistic use of the term 'minorities':

During the seventeenth and eighteenth centuries, however, and still more in the nineteenth, the question of minorities had come to be regarded as possessing a certain international importance, and international treaties dealing with it had been concluded. The existence of these treaties was destined to be of some importance in 1919 as they provided both legal and historical precedents for extending the system. (...) The historical aspect was definitely important, for lessons of history were largely applied both in shaping the new treaties and in constructing the machinery whereby they were applied. (Macartney 1934: 157)

The new discipline of minority studies interpreted the 'nationality question' and the solutions provided in earlier European peace treaties ex post as '(national) minority protection' in such a way because scholars were looking for historical

3 Already the titles of the books show the increased theoretical and terminological interest of the authors: Die geistigen Grundlagen der Minderheitenfrage (Seipel), A kisebbségek nemzetközi védelme (Balogh), Nemzetiségi jog és nemzetiségi politika (Mikó), La protection des minorités de race, de langue et de religion (Duparc), or National States and National Minorities (Macartney).

4 They claimed that what these provisions accorded in the Treaty of Vienna (1815) and the Peace of Berlin (1878) were 'minority rights'. 
precedents. This might be the reason why they introduced the technicallyhistorically anachronistic meta-term of 'minority'.

In 1940, the Hungarian legal scholar Arthur Balogh wrote a short essay on the presence of the word 'minority' and the absence of the word 'national/ nationality' in the Minority Treaties. Balogh calls attention to the lack of the term of 'national minorities' although the treaties were led by the 'nationality principle'. The Minority Treaties applied the term 'racial, religious, or linguistic minorities'. He offers an extensive list of drafts written by Woodrow Wilson, the US lawyer David Hunter-Miller, and the Committee of Jewish Delegation where the term 'national minority' actually appeared (Balogh 1940: 158-163).

Analysing the same corpus, Erwin Viefhaus explained this phenomenon with the direct causal link between the norm of the nation-state and the 'minority problem' in his 1960 book on the origins of the Minority Treaties at the Paris Peace Conference. He concluded that the emergence and consolidation of sovereign nation-states and the renewed problematization of the minority question were interdependent. The origin of the new problematization of the minority question was an attempt to enforce the political principle of the uniform nation-state under the slogan of national self-determination, a political principle of the nineteenth century. ${ }^{5}$

Imre Mikó, a Hungarian legal scholar, observed that there was a substantial difference in the way the notion of 'minority' was used in the 1920 resolutions. The leading idea behind linguistic and cultural rights for minorities was now the democratic principle of equal rights for all citizens. Therefore, the subject of these rights was the individual. 'What was called before the War the "nationality question" is called in the sphere of public law and politics "minority (or better yet "national minority") question since the Minority Treaties (Mikó 1932: 1.1).

Unlike his contemporaries, Mikó appointed the nationality rights in the Habsburg Monarchy as the forbearer of the Minority Treaties and not the precedent international peace treaties. The main difference between the nationality and minority problem is that the first is a matter of internal affairs whereas the second a matter of the international law, says Mikó. Since he did not further elaborate his assertion, it is not clear in what extent he believed what Viefhaus pointed out above: that the minority question is linked to the interpretation of the democratic principle of self-determination as the right to create separate nation-states. Mikó suggests that it was only in 1918 when democratic principles started shaping the rights of citizens in international peace treaties - called subjects before.

5 "Die Entstehung und Konsolidierung souveräner Nationalstaaten und Aktualisierung der Minoritätenproblems bedingten sich gegenseitig." (...) "Die Aktualisierung der Minoritätenproblems ergab sich unmittelbar aus dem Versuch, unter der Parole des Selbstbestimmungsrechtes der Völker die Idee des einheitlichen Nationalstaates und damit ein politisches Prinzip des 19. Jahrhunderts in ganz Europa durchzusetzen” (Viefhaus 1960: VII). 
Since the members of minorities were inferior by definition, the new term of minority referred to a qualitative rather than numeric relation. The communities identified now as 'minorities' struggled with their new denomination that reflected the permanence of their inferior status. In the 1930s, both German and Hungarian legal scholars tried to return to the more neutral expression of 'nationalities' to replace the 'trivializing and dismissive' term of 'minority'. In 1930, German legal scholar Hermann Raschhofer introduced his treatise on the nationality rights with the claim: 'Thus, in order to promote quality over quantity, in this paper, instead of national minorities I will use the word nationality. ${ }^{6}$

Consequently, the 'minority question' integrated both a range of domestic traditions from the Habsburg experiments to solve the nationality question and the European international legal tradition to keep the balance of power and limit the sovereignty of newly established states. Whereas the 'nationality question' was infused with democratic ideas, the ones trying to solve the international security question were less concerned with the democratic idea of equal rights and liberties for all individuals/nations as they were rather embedded in the monarchic tradition.

\section{Why and to Whom? The Historical Context of According 'Minority Rights' before 1918}

Despite the criticism of some of the authors mentioned above, the narrative of continuity and the anachronistic use of the term persisted. It continued to possess a particular influence during the emergence of minority studies as a distinct discipline, and it is considered as scholarly valid and legally binding even by specialists of our days. Since a continuous international history of minority rights is still popular, analytical studies concerning the historicity of the minority term are scarce. To fill this gap, in this part, we will critically analyse the terminology applied in the peace treaties that are listed in the history of European minority protection as legal-formal analogies to the Minority Treaties in 1920.

As we stated above, the legal notion of 'national/religious/racial minority' emerged in 1918, and it was absent from the previous legal texts. The legal-political term in the pre-war years was 'nationalities' (or 'Volksstämme' in the Habsburg case), and the related administrative issues were referred to under the name of 'nationality problem' or 'nationality question'. We will analyse the appearances of the term before 1918 in the next chapter dedicated to the Habsburg case.

6 "Daher wird auch in dieser Abhandlung, um die Qualität in ihr Recht gegenüber der Zahl einzusetzen, anstelle nationaler Minderheit das Wort Nationalität gebraucht" (Raschhofer 1931: 39-40). 
The Congress of Vienna in 1815 is often mentioned as the event that saw the first act of national minority rights. Yet, in the Final Act, we find an ethnonym and not the term 'minority': 'The Poles, who are respective subjects of Russia, Austria, and Prussia, shall obtain a representation, and national institutions' (Final Act of the Congress of Vienna, General Treaty 1815: Art. 1). Concerning the subject of the rights, it would be difficult to argue that the rights were indeed accorded to a 'national group', let alone to individuals in a democratic sense belonging to a 'minority' since the contemporary international legal practice did not recognize national groups as legal entities. Thus, one can argue, that the rights were accorded 'to the memory of the vanished Polish state', not to the (ethnic) Polish nation (Duka Zólyomi 1939: 309-322).

Articles 4, 5, 27, 35, and 44 of the Treaty of Berlin (1878) are considered to confer rights to religious and national minorities in Bulgaria, Montenegro, Serbia, and Romania. The latter four articles guarantee the equality of (persons belonging to) 'different religious creeds and confessions'. Article 4 is often interpreted as a legal act to protect 'national minorities'. The treaty between Austria-Hungary, France, Germany, Great Britain and Ireland, Italy, Russia, and the Ottoman Empire concerning Bulgaria pronounced: 'In the districts where Bulgarians are intermixed with Turkish, Roumanian, Greek, or other populations, the rights and interests of these populations shall be taken into consideration as regards the elections and the drawing up of the Organic Law' (Treaty of Berlin 1878: Art. 4).

Providing special status to members of confessional groups had a deeply rooted tradition. Macartney argues that a new monarch succeeding on the throne commonly took an oath to the Constitution 'to swear to preserve intact the existing institutions and liberties' (Macartney 1934: 158). Taking over possessions from another sovereign was thus a plain extension of this custom. Similarly, on occupying Bosnia and Hercegovina, the government of Austria-Hungary in 1878 pronounced that 'your laws and your institutions shall not be arbitrarily modified; your manners and your customs shall be respected' (Macartney 1934: 171). Because the confessional and national fault lines often coincided in the Balkans, one can read these provisions as protection of national minorities - and maybe all the more in view of the fact that the local states understood themselves as nation-states (Viefhaus 1960: 46-48). Nevertheless, the purpose of these provisions was rather to limit the sovereignty of the newly established states in the name of the principle of religious freedom. Consequently, protecting inferior subjects was not rooted in a modern, democratic but in a monarchic tradition. The nationality question was not at stake in the above-mentioned acts.

The interwar narrative melted the 'nationality question' and the tradition of the treaties in the new concept of minority. Having said that, scholars used separate chapters and terminological toolkits to talk about the two traditions. When Macartney discussed the development of the nation-state in South-Eastern 
Europe and the history of the 'national struggle' in the 'age of nationalism', he applied the terms of 'nation' and 'nationality'. At the same time, he used the notion of 'minority' in the chapter about the history of international minority protection until 1914. We found similar phrasing in Arthur Balogh's book entitled The History of Minority Protection (Balogh 1928). Firstly, he dedicates two chapters to the international history to protect 'confessional minorities'. The third chapter of the book presents the international protection of 'national minorities' between 1815 and 1858. In the fourth and fifth chapters, which discuss the Habsburg legal tradition before and during the First World War, he recurs to the terminological frame of the 'nationality question'.

As demonstrated by these examples, the interwar authors used the term 'minority' anachronistically only when it came to the European international legal tradition, and they never applied it posteriorly to the domestic, Habsburg context. The reason might have been their socialization in the terminology of the 'nationality question', which was thus more familiar and less vague to them, being also open for new interpretations.

To sum up, the existing legal and technical frames enabled the great powers to interpret the 'nationalities problem' within a state as a matter of international relevance in the nineteenth century. The Treaty of Berlin ${ }^{7}$ recognized new states as members of the European state system on the condition that they introduced provisions for 'minority protection': 'the enjoyment of existing religious liberties'. In our view, it was not the democratic idea of equality and liberty that formed the basis of the peace acts but the monarchic tradition to preserve intact existing institutions and liberties and the protection of the international European security. As follows, more often than not the subject of the rights was unclear and open to a number of interpretations. The monarchic tradition blended with the struggle to enforce national self-determination in a uniform nation-state only in the Minority Treaties. Up to this day, defining 'national minority' in legally binding terms is problematic. Bearing this in mind, we will now have a look at the history of the concept in a slightly smaller context: that of the Habsburg Empire.

\section{Contextualizing the Upcoming Problem of 'National Minorities': The Nationalities Question of the Habsburg Empire}

At the dawn of modernity, the 'nationalities question' became the topic of heated discussions throughout Europe due to the new-found appearance of national movements. This problem was especially acute within the highly diverse

7 Similarly, the Peace of Waadt (1665), the Congress of Vienna (1815), the Peace of Bucharest (1913), etc. (Macarteny 1934: 158). 
Habsburg Empire - not a nation-state but a composite monarchy which was the host not only to various ethnicities but also to legal traditions and, accordingly, viewpoints on the national idea.

In the so-called hereditary crownlands (Kronländer) of the Habsburg dynasty, the uses of the terms 'people' (Volk) and 'nation' (Nation) or 'nationality' (Nationalität) accommodated the legal-territorial traditions of the provinces. In various local interpretations, native populations constituted the singular nationality of each territory, this possibly being divided into parts (Theile) or tribes (Stämme) of different ethnicities. Such was the case of Moravia, in the diet of which various representatives argued for the co-existence of Slavic and German populations in the framework of the 'Moravian' nationality during August 1848 right after the Spring of Nations and the Viennese revolution in the March of the same year (Stourzh 1985: 23).

This period also saw attempts to establish a political community for the whole empire. In line with these, the terms of Volk and Nation gained a wider meaning in the newly-assembled Imperial Council (Reichstag) of 1848. These terms now referred to the entire population of the Habsburg Monarchy, which was, on the other hand, divided into various 'tribes' or ethnicities (Volksstämme), each united in its sense of 'nationality' through language and culture (Stourzh 1985: 23). As Jászi frames it in 1912, 'today we understand by nation a nationality that possesses the state power, whereas a nationality, in the strict sense of the word, lives without state power under the unfavourable legal and administrative rule of a foreign nationality' (Jászi 1912: 2).

Although the initial attempts to create a parliamentary monarchy failed in 1848/49, these ideas re-appeared in the wake of the Habsburg Empire's transformation into the dualist entity of Austria-Hungary after the Compromise (Ausgleich / kiegyezés) between Emperor Francis Joseph and the Hungarian élite in 1867. The Cisleithanian, i.e. Austrian part of the empire, the 'Kingdoms and Lands Represented in the Imperial Council' (Die im Reichsrat vertretenen Königreiche und Länder) received its fundamental laws with the December Constitution (Dezemberverfassung). Article 19 codified the 'equality of nationalities' (Gleichberichtigung der Nationalitäten), all of their native languages and the right of the nationalities to receive education exclusively in their mother tongues. Thus, the Austrian part of the Monarchy had no dominant nation defined by its legal framework; in effect, it was constructed to be a 'nationalities state' (Stourzh 1985: 53-56).

As opposed to these developments, the dominant narrative in the Lands of the Hungarian Crown went through different phases. The ethnic Hungarian (Magyar) narrative of the early nineteenth century identified 'nation' (nemzet) not as a cultural but rather a historical-legal entity with close ties to statehood. According to this interpretation, only two nations existed in the territories united 
under the sceptre of St. Stephen: the Hungarian and the Croatian ones. All other ethnic populations counted as 'nationalities' (nemzetiségek). As for their future, the dominant Hungarian discourse envisioned their assimilation into their respective political nation due to the effects of abolishing serfdom and granting equal rights to all citizens in the future - which ideas remained dominant during the Revolution of 1848. Enacted by the new Hungarian Parliament, the so-called April Laws did not recognize any other national entities within the framework of the state but the Hungarian one itself (Gyurgyák 2007: 35-64).

Besides, the experiences of violent intra-ethnic conflicts during the subsequent Hungarian War of Independence and the period afterwards successfully modified this viewpoint. As a result, the new Hungarian establishment after the Ausgleich of 1967 tried to accommodate towards the other ethnic communities of the country. Thus, while the Nationalities Law (nemzetiségi törvény) of 1868 maintained the idea that there was only one nation in the Transleithanien part of the Habsburg Empire, it conceived this community to be a civic or 'political' one (politikai nemzet) comprised of various nationalities. Apart from being recognized as separate entities, the latter also received cultural rights in connection to the use of language in education, the lower strata of administration, and the establishment of cultural associations (Gyurgyák 2007: 65-78).

One could rightfully view the legal traditions of Trans- and Cisleithania as being fundamentally different, one leaning towards the establishment of a multinational community, while the other aiming to create a nation-state. At the same time, it is without a doubt that while the laws of 1867 and 1868 both tried to accommodate existing historical structures with the new concept of nations, they could not entirely resolve the nationalities question in either part of the Habsburg Monarchy. The representatives of non-dominant ethnicities argued for further autonomy and the subsequent federalization of the empire that brought up various questions. The isolation of national communities did not only threaten the contemporary patterns of co-existence but also problematized the existence of 'national minorities' (Stourzh 1985: 15-16). However, any attempt to describe the situation using this term seems anachronistic in retrospective, as we will see - since the contemporaries did not use such a legal concept.

\section{'Nationality' and 'Minority' in the Legal Language of the Habsburg Monarchy}

In the Austrian legal tradition, both the dominant public discourse and the laws focused mainly on the concept of 'nationality' - not on that of 'minority' - and the questions accompanying its use. 'The concept of national minorities belongs to the theory of the nation-state. Neither the supranational nor the non-national 
state are familiar with national minorities. In the old Austria, which is the classic example of a supranational state, there were only Volksstämme.'

Parallel to this tendency, the issue of equal rights and liberties of all nationalities and the question of who comprises the majority of the population on a given territory appeared more and more often in newspaper articles and political pamphlets. The expression 'the rule of minority/majority' alluded to the opposing democratic and elitist views of modern society and the antagonism between the idea of majority rule and the notion of a governing minority (Bottomore 1993: 8). To balance the power between (numeric) majority and (a superior or inferior) minority, many of the authors suggested the introduction of vetoing.

In the Habsburg Empire in the 1860s, the term 'minority' appeared more and more often in reference to ethnic relations. This marked the first step towards imagining the concept of 'national minority' in the sense of the post-1918 era. In the Hungarian language before 1918, the meaning of the word 'minority' and its collocates referred to a quantitative relation and a transitory state. In the sixteenth century, the term 'minority' still comprised different connotations. It had a derogatory meaning referring to a loss in prestige, a shameful occurrence that lessens the injured party (kisebbségére van). In the nineteenth century, 'being in a minority' referred to a concrete decision-making situation. 'Being in a minority/majority' (the two terms usually appeared jointly) was related to exercising power in political, military, or confessional areas. The dictionary of Czuczor-Fogarasi in 1865 defines 'minority' as a proportional relation due to which one is consisting of less parts or numbers than the other part. He gives the example of the minority position of a party filing a motion, meaning that the opposition was more numerous than the party making the proposal. ${ }^{9}$

In a national or confessional context, 'minority' was understood also in quantitative-relational terms. It appeared usually in noun phrases where the 'minority/majority' is the noun modified by quantifiers or adjectives (a 'vast majority', ${ }^{10}$ 'a small minority'11). Hungarian political thinker József Eötvös wrote in 1840 in an article about Jewish emancipation: 'here, where the entire population, oppositely to a small minority of a different confession, is privileged'12 (Eötvös

8 "Der Begriff der nationalen Minderheit gehört der Theorie des Nationalstaates an. Weder der übernationale, noch der nationale Staat kennen eigentlich nationale Minderheiten. Im alten Österreich, jenem Musterbeispiel eines übernationalen Staates (...) gab es nur verschiedene Volksstämme” (Seipel 1925: 3).

9 „Bizonyos mennyiségnek, mekkoraságnak azon viszonyos állapota, melynél fogva egy másikhoz mérve kevesebb részekből vagy számból áll. Az inditványozó pártja kisebbségben maradt, azaz többen voltak az ellenpártiak" (Czuczor-Fogarasi 1862: 848-849).

10 „Ezt az ellenzék ügyesen tudta felhasználni s a sok kör, egyenlőségi és más társaságok lármás segítségével a vezetőnek annyira imponált, hogy a roppant többség ellen majdnem mindig a kisebbség akarata győzött (Szokoly 1867: 78).

11 „,...) Kossúth mégis egy kis minoritás által befolyásolni hagyta magát” (Szokoly 1967: 187). 
1840: 155). The other interesting aspect of the quote is that the author spoke of a 'minority' not in a parliamentary but in a sociological (demographic, statistical) sense $^{13}$ (Gleason 1991: 392-424). When applied to a territory, an administrative unit, 'being in a minority' described a permanent state that is independent from a decision-making situation. Hungarian publicist Samu Szeremlei wrote in 1867: 'The memory of the annihilation of the Serbian Empire by the Turks in the Battle of Kosovo (1498) and of having been an independent nationality has always prompted some of Hungary's Serbs to strive for an independent Serb province despite the fact that they are scattered and in a minority in relation to other peoples [népfajok]' (Szeremlei 1867: 93).

Similarly, in the example above, the term minority was still used in a relational sense: 'they are scattered and in a minority in relation to other peoples'. Deriving from this numeric and relational sense, we can interpret the concept of 'minority' after 1918 as a synecdoche. ${ }^{14}$ It was only after the emergence of this new, compressed notion of 'minority' that the word appeared as a modifier (adjective) in phrases like 'minority rights', 'minority protection', or 'minority question'. In addition, (similarly to the Polish case at the Congress of Vienna) when the Serbs strive for an independent province, they justify their claim with their independent political nationality. The Serbs do not ask for individual rights or for autonomy as an ethnic group but as a long-ago state.

Meanwhile, the issue of minorities had also made its implicit way to the legislation. Article 19 of the December Constitution in the Austrian part of the Empire safeguarded the right of native populations to receive education in their mother tongues for a good reason, with the prohibition of enforcing the learning of another language. In fact, this was a concession to the representatives of the Bohemian German community who nurtured fears of having to accustom to the culture of the Czech majority inhabiting their crownlands (Stourzh 1985: 26).

The occasional appearance of the term 'national minorities' in the political literature showed a new interest to deal with the problem of separate administration for different ethno-linguistic (or even confessional) groups. For instance, Adolf Fischhof, one of the main authoritative political figures from the era of Cisleithania's establishment also elaborated on the subject. In line with the contemporary German liberal ideas, Fischhof maintained the idea of German cultural superiority and civilizational mission towards the Slavs. Yet, he

13 Gleason distinguished between a non-sociological and a sociological sense of the concept in his article about the American concept of minority in the twentieth century. The non-sociological sense included usages such as a person not of age or what the author calls 'political' sense when minority referred to a party in numeric minority. The sociological sense referred to the analytical category of minority as 'a category at a lower level than a nation' to designate 'distinct cultural communities' that were known to exist but which were not to be considered 'nations'.

14 A figure of speech in which a part is made to represent the whole or vice versa. In our case: 'minority' instead of 'in a minority in relation to...' 
proposed the federalization of the Habsburg Empire to put an end to the national struggles - which had its connections to the existence of minorities (Reifowitz 2001: 441-442).

The term 'minority' (Minorität) appeared frequently in the main work of Fischhof titled Österreich und die Bürgschaften seines Bestandes (1869) in a quantitative as well as in a relational sense. For instance, he drew parallels between the status of national and political minorities, claiming that each deserved protection from the oppression of the majority (Majorität). The minority did not only appear as a subject of oppression in Fischhof's book but also in the role of the oppressor as he argued against the rule of German and Italian minorities over the local Slavic majorities in the provinces of Bohemia, Moravia, Dalmatia, and the Littoral. He pointed out that the introduction of veto rights would prevent the abuses of power on local administrative and legal levels; Fischhof did not propose to institutionalize minority communities as distinct entities (Fischhof 1869: 70, 185-186, 196). The phrase 'national minority' (nemzeti kisebbség) appeared in the Hungarian language for the first time in a review of Fischhof's book ${ }^{15}$ (B[ródy] 1869: 1-2). Both the interest in the subject of the work and the word-to-word translation of the term of 'national minority' show that a new burning question was looking for appropriate wording in the Hungarian part of the Monarchy as well.

In 1898, Georg Jellinek, a professor of Public and International Law at the University of Heidelberg gave a talk at the Law Society of Vienna on the subject of 'minority rights' (Das Recht der Minoritäten). In his talk, Jellinek presented the history of the majority principle in modern democracies in which individual rights too are playing an increasingly important role (Jellinek 1898: 43.). Since the majority rule leads to the rule of the masses, the levelling of the society, and the vanishing of individuality, minority rights serve to equilibrate these deflections of the modern democracies. Minority rights originate from the desire to avoid the unregulated struggle between national, religious, or social groups (Jellinek 1898: 1). We should nevertheless keep in mind that Jellinek raised the question of minorities and majorities solely in the context of legislative bodies.

Similarly, in his book written in the aftermath of the 1848 Revolution, Hungarian political thinker József Eötvös analysed ways to represent ethnicities that found themselves in a numeric minority in a multinational democracy (Eötvös 1850). His biggest concern was the conflict of interests between nationalism and the democratic principles of equality and liberty. The first one, nationalism, pursues predominance and separatism instead of equality, argued Eötvös. National claims based on the democratic principle of people's sovereignty and a government based on the decision of popular majority are thus mutually exclusive in a multinational

15 „A foederatio hozandó be, s a nemzeti kisebbségek oltalmára bizonyos tartományok számára egy nemzetiségi törvény alkotandó, a mely a nemzetiségeknek biztositsa a teljes egyenjogosságot, a mi az iskolát, egyházat, közigazgatást, igazságszolgáltatást s a törvényhozást illeti.” 
state like the Habsburg Monarchy ${ }^{16}$ (Gángó 1998: 377-382). The predominance of a national majority on a given territory is "absolutism" and contradictory to the idea of a constitutional state (Fenyő 2007: 127-134). Thus, implementing the national principle will result in the dissolution of the monarchy. An ethnic solution that is satisfactory for all parties will abolish the Hungarian-Austrian frontiers because most of the nationalities have ethnic co-nationals beyond the borders of the Empire (Gángó 1998: 390). What is more, even if the nationalities of the Monarchy create their own sovereign states, the principle of ethnic majority cannot solve the problems of territories having inhabitants of more than two ethnicities and no absolute national majority ${ }^{17}$ (Kann 1950: 94-95).

In his 1865 book on the nationality question, Eötvös pleads that the solution is not the application of the majority principle but consensus (Demeter 2016: 238-260). He develops a model based on the autonomy of the municipalities. The autonomous municipalities limit the power of the central government, which Eötvös interprets as the embodiment of the Rousseauvian 'general will of citizens' or the 'tyranny of the majority' in Tocqueville's expression - that is closer to the author's understanding. What is important in Eötvös's argumentation is that he recognized the complex relations and antagonisms between territory, sovereignty (as the rule of the majority), and nationalism. The roots of Eötvös's solution were strategies from the Middle Ages to manage confessional diversity within a territory. Nevertheless, it is clear that Eötvös is aware of and concerned about the differences between religion and nationality - as most of the political thinkers of his time. Moreover, his solution implies that the right of minorities cannot arise from popular sovereignty but only as an inalienable right of the communities themselves. The implementation of minority rights needs to be taken out of the hands of the majority and has to be introduced as fundamental law.

Jellinek too places great emphasis on the idea of fundamental laws (leges fundamentales). He shows that in the sixteenth century fundamental laws were sacred; therefore, the monarch had no right to abolish them ${ }^{18}$ (Jellinek 1898: 7).

16 „Entweder man erkennt die absolute Sovierainität der Majoritäten an, und dann wird diese Majorität - eben in solchen Zeiten wo nationelle Bestrebungen bestehen - seine Macht zur Unterdrückung jeder in der Minderheit befindlichen Nationalität gebrauchen, bis der Begriff des Staates mit dem des Volkstammes identisch geworden ist. Oder man erkennt die absolute Souverainität der Majorität nicht an, und stellt für jede einzelne Nationalität gewisse unveräußerliche Rechte fest, welche außer dem Gebietskreise der Souverainität liegen und dem Augenblicke, als man dieses gethan, hat man auch die Idee der Gleichheit und Freiheit - beide Begriffe immer in jenem Sinne verstanden, den man ihnen jetzt beilegt, aufgegeben” (Eötvös 1850: 30).

See also: Eötvös 1850, Chapter 7 (Das Prinzip der Gleichberechtigung aller Nationalitäten kann in der österreichischen Monarchie nie vollkommen durchgeführt werden).

In the seventeenth century, Hobbes equated the concept of fundamental law with the social contract on which the society is based on. The Levellers too came up with a constitution including the 'agreement of people', a list of fundamental rights that are not subject to the decision of the parliamentary majority. In the continental tradition, Chr. Wolff put a stress on the importance of fundamental laws as a limitation of the legislative power. In the American 
The origins of the idea to limit the power of the sovereign/majority and to protect those in a (parliamentary) minority is the belief that there are actual fundamental laws within the very foundations of human society. This belief originated from the religious tradition and natural law. By the end of the nineteenth century, the tradition of 'sacred' laws transformed into the delimitations that restrained the amendment of the constitution (Jellinek 1898: 18).

The tradition of natural law claims that all nations are uniform (einheitlich) and all individuals are of equal value (gleichwertig). Starting from this statement, Jellinek's contemporaries believed that the rights of the minorities go as far as the rights of the individual. Nevertheless, the principle of majority has always been widely criticized in states torn by antagonisms (for example, Germany after the Thirty Years' War, when religious enmity took a political shape) (Jellinek 1898: 27). To avoid the rule of the simple majority, the conflicting political parties introduced the curial vote and the amicabilis compositio (i.e. decision-making based on the compromise of the two parties). ${ }^{19}$ Jellinek argued that national conflicts marked similar fault lines in contemporary society. In the lack of inner uniformity, 'majorization' (Majorisierung) appears as 'brutalization'. He sharply criticized the presupposition of the equality (Gleichheit) of all people on which the majority principle is based and argued for the protection of minorities and for the implementation of national privileges by legal means. ${ }^{20}$

Jellinek imagined the future minority right as one exercised through the institutions that represent minority interests. He distinguished between numeric (quantitative-relational) and constant (qualitative, i.e. superior/inferior) minorities. Constant minorities were bound by an inner common interest such as confession or nationality. When it came to the protection of minorities, the author preferred individual solutions since the cases where minority protection applies is different (Jellinek 1898: 39). The best means of exercising the right of the minority is, in Jellinek's opinion, the veto. Eötvös and Jellinek, however, had their own stakes in studying the issue of the tyranny of the majority and the ways to protect the minority since the two authors were members of the 'dominant

constitutional tradition too, the idea of 'fundamental orders' had an important role as an act of state creation of the colonies.

19 He later claimed that Germans became a numeric minority in Austria compared to the Slavic majority and suggested the creation of a Corpus Germanorum in the Austrian Parliament, which would protect the Germans against outvoting (Jellinek 1898: 29).

20 Such measures in Austria were the introduction of language rights, the 'rounding off' (Abgrenzung) of multilingual administrative units, the introduction of national tribunals, the creation of nationalities' sections in state administration and that of the municipalities, and finally the introduction of national curiae in the state diet (Jellinek 1898: 30-31). As for England, he referred to Calhoun and Maine. Calhoun sees the key to minority protection in the principle of veto and compromise while Maine in that of the obstruction (Jellinek 1898: 34-35). Jellinek also considered abstinence and secession as legal means of exercising power for minorities (Jellinek 1898: 38). 
nations' in their states. Yet, both in Austria and Hungary the 'dominant nation' was in a numeric minority.

The famous book of the Austro-Marxist Otto Bauer entitled 'Social Democracy and the Nationalities Question' (Sozialdemokratie und die Nationalitätenfrage, 1907) took further steps in this direction. It is worthwhile to remember that contemporary Austrian Social Democracy struggled with the influence of nationalist movements both as competitors to class-based identity and forces to disturb the unity of the labour movement itself. The antagonism between German and Czech representatives with regard to the national question appeared already at the Party Congress of 1891, mere four years after the foundation of the political organization. Giving in to the Slavic demands, the party reorganized itself along national lines and proclaimed its support for the reorganization of the Habsburg Monarchy at the Brno Congress of 1899 (Knapp 1981: 82-95). Yet, territorial ideas with concerning an ethnically diverse empire necessarily meant the problematization of the existence of local national minorities. Bauer's work was actually the most famous and influential one in a series of Austrian socialist literature pieces dedicated to the problem - and his propositions had a deep importance in such contexts.

In his analysis of national conflicts, the socialist politician actually identified the problem of 'national minorities' (nationale Minderheiten or nationale Minoritäten) as one of the main factors behind mutual aggressions. In view of the inextricable mixture of ethnic populations in the lands of the Habsburg Monarchy, Bauer rejected the solution of the nationalities question on the basis of the 'territorial principle' (Territorialprinzip). Conversely, he preferred the socalled personality principle organization (Personalitätprinzip) that would have introduced national communities defined by membership as legal entities to be invested with rights to manage their own cultural and administrative issues. The influential Social Democratic thinker also proposed that minorities should become 'autonomous bodies' (öffentlich-rechtliche Körperschaften) as a means to provide the same rights for them as for those of the main national communities and to put an end to national quarrels (Bauer 1907: 222, 294, 314, 460). Thus, Bauer actually identified minorities as qualitative phenomena with distinct rights to be received in the future.

The socialist politician was not the first one to come up with these ideas - in fact, solutions based on either territorial or personal grounds (or their combinations) appeared in the propositions of others or the influential works of Karl Renner (Knapp 1981: 94-98). Yet, all of these ideas actually foreshadowed the appearance of 'national minority' as a legal category in the political discourse in the era in which great changes were coming up - the First World War. 


\section{'National Minorities' in the Discourse of the House of Representatives of the Multinational Austrian Reichsrat (1917-1918)}

Up until 1914, the imperial government of Austria aimed to manage the difficult relationship between various national communities through the principle of 'equality of nationalities' (Gleichberichtigung der Nationalitäten) (Stourzh 1985: 8-9). This idea became effective in various ways; for instance, ethnic groups could represent themselves increasingly in the legislative body of the Imperial Council (Reichsrat) with the subsequent enlargements of suffrage. This, however, resulted in the escalation of national conflicts within the framework of the Imperial Council - which also made its proper legislative work almost impossible for long periods. Due to this fact, Emperor Francis Joseph suspended the Imperial Council with the outbreak of the First World War (Adlgasser 2014: LV, LXIV-LXV). It was the successor of the old monarch, Charles I, who convened the Imperial Council together again in 1917. Various factors contributed to this decision: the new emperor saw dire needs of reform and liberalization in the wake of the war difficulties and the effects of the recent February Revolution in Russia (Rumpler 2016: 1168-1169).

Thus, the parties of many nationalities could raise their voices and concerns in connection to national and imperial issues on 30 May 1917, upon the re-opening of the Reichsrat. One of the key expressions of the time was the right of 'national self-determination of peoples' (Selbstbestimmungsrecht der Völker), popularized most recently by events in revolutionary Russia (Manela 2009: 37). This expression had various meanings and usages at the early stage of its history. For instance, the parties of Slavic nationalities and the German Social Democrats in the Reichsrat understood the notion as a democratic one referring to the will of the populations represented by them. ${ }^{21}$ As such, they argued for the institutionalization of 'national-territorial autonomy' (national-territoriale Autonomie) and the creation of a federal state (Bundestaat) out of the Habsburg Empire. ${ }^{22}$

According to these politicians, the main obstacles to these reforms were the contemporary trends of centralism (Zentralismus) and the rule of the numerically inferior Germans in the Monarchy. According to their viewpoint, this minority opposed the bulk of the national groups and was antagonistic to the new Zeitgeist introduced by the February Revolution of Russia. 'The current times are not in support of the hegemony of minorities. The one who aims to maintain the

21 The speech of the Young Czech Adolf Stránský in the Reichsrat. 4. Sitzung der XXII. Session am 12. Juni 1917, in: Stenographische Protokolle über die Sitzungen des Hauses der Abgeordneten des Österreichischen Reichsrates: (Wien 1907-1914), 135.

22 The speech of the Ukrainian National Democrat Eugen Petruszewycz in the Reichsrat. 8. Sitzung der XXII. Session am 16. Juni 1917, in: Stenographische Protokolle über die Sitzungen des Hauses der Abgeordneten des Österreichischen Reichsrates: (Wien 1907-1914), 374. 
hegemony of minorities goes against the current spirit of the time, does not understand this great age and will be crushed by the great and general world current; he can do there what he wants' - summed up this viewpoint Czech agrarian politician František Udržal on 6 July 1917, talking about the oppressive tendencies of the German national character and politics in Austria. ${ }^{23}$ Minority appeared once again as a quantitative term, designating the disproportionate and despotic power of a numerically inferior group over others in the context of struggles for democratization. In this sense, the notion maintained its meaning since the times of Fischhof.

However, 'minority' soon gained a new understanding with the transformation of the Eastern European landscape. In November 1917, the radical Marxist group of the Bolsheviks overthrew the Provisional Government of Russia and proclaimed the victory of a new revolution - one that utilized the notion of selfdetermination extensively. V. I. Lenin and his comrades hoped to gain support from the non-Russian nationalities and the oppressed populations of the imperial world for the cause of their revolution through an extremist interpretation of the concept (Unterberger 1989: 83-84). The latter was analogous to secession in their understanding (Tarr 1999: 101).

However, the Central Powers - the allied states of Germany and the Habsburg Monarchy - also made use of the notion for their own sake, arguing for the detachment of peripheries from the Russian Empire. Due to the cracked nature of the latter state that also sank slowly into a raging civil war, it was natural that the German and the Austro-Hungarian interpretation became dominant during the peace negotiations between the three governments at Brest-Litovsk (Chernev 2011: 373, 379).

As a result, new nation-states appeared on the Eastern European scene. One of these was the Ukrainian People's Republic that inherited an ethnically diverse landscape from the Russian Empire. As a result, its Parliament (Rada) recognized the various ethnic groups as legal entities and invested these with rights to 'national-personal autonomy' in January 1918 (Magocsi 2010: 536).

On 22 January 1918, a group of Austrian Ukrainian representatives raised concerns in connection to the behaviour of the Habsburg Empire towards their newly independent kin-state. The members of the group 'Ukrainian National Representation' interpellated the government in this regard, with a special focus on the issue of national minorities:

23 „Für die Hegemonie der Minoritäten ist die jetzige Zeit nicht. Wer noch die Hegemonie der Minoritäten zu halten trachtet, der verkündigt sich an dem Geiste der Zeit, der versteht nicht die große Zeit und wird von der großen allgemeinem Weltströmung zermalmt; da kann er machen, was er will.” 15. Sitzung der XXII. Session am 6. Juli 1917, in: Stenographische Protokolle über die Sitzungen des Hauses der Abgeordneten des Österreichischen Reichsrates: (Wien 19071914), 690. 
Is the government ready to explain why did Count Czernin take a prominent stance for the protection of the Polish minorities in Ukraine while negotiating with the assignees of the Ukrainian Republic. He must have known about that the Polish minority has its representative in the Ukrainian government and that the disappearing Polish minorities in the Ukrainian Republic were entitled to a full national autonomy. At the same time, the native Ukrainian population in Eastern Galicia - which is not even a minority but an overwhelming majority of the land's population is not only refrained to have an influence on the government of the land but even more, the Ukrainian population has been left extruded without protection to a minuscule Polish minority? ${ }^{24}$

The comment of the Ukrainian representatives on the issues of their kin-state followed old lines of argumentations - now enriched with quite modern elements. The Ruthenians had long problematized the rule of the Polish nobility over the province of Galicia, the population of which was in a large portion Ukrainian in the Eastern parts of the land. In their view, it was the principle of the 'equality of nationalities' that suffered harm due to the compromise between the Polish élite and the imperial government in 1868 (Binder 2006: 242, 252-255). Naturally, the representatives of the 'oppressed' ethnicity argued for the separation of their territories and the creation of their own province on the basis of selfdetermination in the First World War. ${ }^{25}$ However, the comparison of the status of the Ukrainian nationality in Austria and the Polish minority in Ukraine brought a new element into the discussion. The Ruthenian representatives now referred to a qualitative concept used within the framework of the Ukrainian nation-state - which, in their eyes, had its relevance in the imperial framework. While they based their main ideas upon the concepts of nationality and self-determination, the safeguards for national minorities in Ukraine served with a positive example for them as for the settling of national conflicts. In consistence with these ideas, representative Eugen Lewickyj later argued that the Ukrainian question of the

24 „Ist die Regierung bereit, aufzuklären, weshalb Graf Czernin bei den Friedensverhandlungen mit den Bevollmächtigen der Ukrainischen Republik sich vor allem für den Schutz der polnischen Minoritäten in der Ukraine exponierte, da ihm doch bekannt sein mußte, daß die polnischen Minoritäten in der ukrainischen Regierung ihren Vertreter haben, und daß den polnischen verschwindenden Minderheiten in der Ukrainischen Republik eine volle nationale Autonomie zuerkannt wurde, während in Ostgalizien der ukrainischen bodenständigen Bevölkerung, welche nicht einmal eine Minderheit, sondern überwältigende Mehrheit des Gesamtbevölkerung des Landes darstellt, nicht nur jeder Einfluß auf die Verwaltung des Landes abgesprochen, sondern vielmehr das ukrainische Volk einer verschwindenden polnischen Minderheit schutz- und rücksichtlos ausgeliefert wurde?” 53. Sitzung der XXII. Session am 22. Jänner 1918, in: Stenographische Protokolle über die Sitzungen des Hauses der Abgeordneten des Österreichischen Reichsrates: (Wien 1907-1914), 2803.

25 15. Sitzung der XXII. Session am 6. Juli 1917, in: Stenographische Protokolle über die Sitzungen des Hauses der Abgeordneten des Österreichischen Reichsrates: (Wien 1907-1914), 690. 
Habsburg Empire could only be solved through the guarantees of territorial autonomy and the rights of minorities of other languages (anderersprachiger Minoritäten) in relation to the concerned areas. ${ }^{26}$

This idea advanced even further in the case of the Czech national movement. While the exile movement headed by T. G. Masaryk famously argued for the cause of Czechoslovak secessionism in foreign lands, the locally active politicians of the nation still tried to find ways to accommodate their ideas with the existing reality of the Habsburg Monarchy. The historical aim of Czech parties was to achieve the unification of the so-called 'Lands of the Crown of St. Wenceslas' Bohemia, Moravia, and Silesia - and to ensure their autonomy within the empire. Nonetheless, these lands also hosted a sizeable German community antagonistic to these aims. As opposed to the vindication of the Czech historical state rights (Staatsrecht), the Germans argued for the division of the ethnic populations on the level of provincial districts (Kreiseinteilung) (Helmut 2016: 1180).

With the entrance of the concept of self-determination into play, both parties started to use the notion to further reinforce their ideas - but also complemented these during the process. The representatives of local Germans argued for the total separation of their territories from the Czech-inhabited lands and the creation of a separate 'Bohemian German' province (Deutschböhmen) within the empire. In their eyes, this was according to the will of the population embodied by them as opposed to the 'false' combinations of self-determination and Staatsrecht on the Czech side. ${ }^{27}$

If the Czech representatives wanted to maintain their claims to the entirety of their historical lands, they obviously needed to promise safeguards for the German community as for their untroubled existence in the future Bohemian state. It was the Young Czech Adolf Stránský who first attempted to deal with this issue in his speech on 12 June 1917 in the Reichsrat. He stated that the smaller population would receive national autonomy (nationale Autonomie) in the to-be-created Czecho-Slovak territorial entity of the Habsburg Empire. ${ }^{28}$ The future comments of Stránský also showed how the Czechs conceptualized their community and accustomed their ideas to the reality of multi-ethnicity. As the representative argued on 6 December 1917, this territorial entity would constitute a 'state nation' (Staatsnation). The politician used the example of Hungary to point out the valid nature of Czech historical claims - a national community that also defined itself as a multi-ethnic one. ${ }^{29}$

26 78. Sitzung der XXII. Session am 19. Juli 1918, in: Stenographische Protokolle über die Sitzungen des Hauses der Abgeordneten des Österreichischen Reichsrates: (Wien 1907-1914), 4098.

27 15. Sitzung der XXII. Session am 6. Juli 1917, in: Stenographische Protokolle über die Sitzungen des Hauses der Abgeordneten des Österreichischen Reichsrates: (Wien 1907-1914), 690.

28 4. Sitzung der XXII. Session am 12. Juni 1917, in: Stenographische Protokolle über die Sitzungen des Hauses der Abgeordneten des Österreichischen Reichsrates: (Wien 1907-1914), 137.

29 48. Sitzung der XXII. Session am 4. Dezember 1917, in: Stenographische Protokolle über die 
Not surprisingly, the Czech representatives could make great use of the example of the new Eastern neighbour in this regard. Once again, this happened on the very same day as the codification of the Ukrainian law on 'national-personal autonomy' - which shows us the remarkable speed of information transfer in this period. Czech National Socialist Václav Klofáč delivered a speech that made an explicit connection between this and the claims of his own national movement.

We want total freedom also for the Germans; so, the Germans can also be very satisfied with us. The free Ukraine shows us how the Slavs understand the solutions of these national questions. [...] Our predecessors also proposed a similar national law to the German inhabitants in 1871, a guarantee against the oppression of the minority, also with the veto for the national curia. ${ }^{30}$

Thus, Klofáč both brought in and accommodated the qualitative concept of national minority into the framework of Czech argumentation. In his view, the future nation-state of his community would have used the Ukrainian example proactively to solve the conflict between the Slavic and the German population in Bohemia. Klofáč also historicized the concept with regard to the Czech national movement, arguing for earlier occurrences in its discourse.

In sum, the concept of 'national minority' was a rather complementary one to that of self-determination - however, with important patterns in its use. While it was the birth of the (Ukrainian) nation-state that put the notion into effect, the nationalities of the neighbouring Habsburg Empire adopted it for the cause of their old arguments for imperial reform. In the Ruthenian case, minority was analogous to nationality, and the representatives of the national movement aimed at providing equal rights for their community in parallel with the legal procedures in Ukraine. Their main goal, however, was not to receive minority rights in the province of Galicia but to validate their own self-determination in a territorial sense. As opposed to this, the Czech deputies in the Imperial Council proactively built the notion into their arguments for their to-be-erected nation-state. They attempted to use the concept of national minority to settle the conflicts within two different ethnic communities hosted by the Czech historical lands, while the latter was to be still part of the Habsburg Empire.

Sitzungen des Hauses der Abgeordneten des Österreichischen Reichsrates: (Wien 1907-1914), 2535.

30 „Wir wollen die vollkommene Freiheit auch für die Deutschen; also die Deutschen bei uns können sehr zufrieden sein. Die freie Ukraine zeigt uns, wie die Slawen diese nationalen Fragen zu lösen verstehen. [...] Auch unsere Vorgänger haben bereits im Jahre 1871 den deutschen Landsleuten ein ähnliches Nationalgesetz angeboten, eine Garantie gegen die Vergewaltigung der Minorität, auch mit dem Veto für die nationale Kurie.” 53. Sitzung der XXII. Session am 22. Jänner 1918, in: Stenographische Protokolle über die Sitzungen des Hauses der Abgeordneten des Österreichischen Reichsrates: (Wien 1907-1914), 2814. 
One could object to these claims, stating that by early/mid-1918 many nationalities - or at least some of their political parties - started to think of their future outside of a crumbling empire. Yet, we argue that while national minorities came into existence within the framework of the nation-state, the problem already came up within the structure of the empire during the First World War. In fact, the attempts to conceptualize national units in connection with the still existing Habsburg Empire problematized the qualitative notion of national minorities. These designated a profound change in the use of the expression in line with the transformation of local power structures. As such, the minority question appeared as a sub-topic of the nationalities question and national conflicts within the empire. However, the defeat of the Habsburg Monarchy and its dissolution into nation-states at the end of the First World War shed an entirely new light on the stakes of these discussions. In October 1918, the representative of the Italian People's Party, Giuseppe Bugatto, pointed at these problematics effectively:

Should indeed a change occur where not a multitude of minorities defend themselves against the plurality of majorities, but we [the dispersed Italian community - L. B. B.] are becoming parts of a simpler state, whether it be a German, a Southern Slavic, or any other one, in which we will only have one opponent, then it will be all the more necessary that the rights of minorities, which we claim, would be secured. ${ }^{31}$

\section{'National Minorities' in the Discourse of the Hungarian Nation-State's Parliament}

In contrast with its Austrian neighbour, Hungary developed on the road of becoming the nation-state defined by the Nationalities Law of 1868. Over time, ideas concerning the ethnic Hungarian essence of the polity and the eventual assimilation of the nationalities (Magyarization) became stronger among the élite at the turn of the century. This phenomenon brought with it the resistance of other ethnic groups. These either strived for the protection of their existing rights or aimed at achieving the status of a 'nation' and to transform Hungary in line with their national goals (Szabó 2016: 679-681, 684).

31 „Soll wirklich eine Änderung dahin geschehen, daß dann nicht mehr eine Pluralität von Minoritäten sich gegen eine Pluralität von Majoritäten zu wehren hat, sondern daß wir in einen einfacheren Staat kommen, sei es in einen südslawischen oder einen deutschen oder einen anderen, in welchem wir nur einen Gegner haben, so ergibt sich daraus die um so größere Notwendigkeit, daß die Minoritätsrechte, die wir beanspruchen, ganz gesichert werden." 91. Sitzung der XXII. Session am 11. Oktober 1918. Stenographische Protokolle über die Sitzungen des Hauses der Abgeordneten des Österreichischen Reichsrates: (Wien 1907-1914), 4617. 
However, these aims were hard to pursue in the Hungarian context given the severely limited nature of suffrage in the country. Such regulations were in service of the domination of the pro-Dualistic Hungarian élite against oppositional, national, and social movements alike threatening the establishment. As a result, only a few representatives of non-Hungarian nationalities could enter the building of the Parliament in the years preceding 1914 (Judson 2016: 267-268). Their position was made difficult by the fact that the Hungarian legal system also punished any oral acts, 'nationality instigations' (nemzetiségi izgatás) against the formula of state unity - these not being precisely defined. ${ }^{32}$

The ideological changes of the First World War - and mainly the concept of national self-determination - brought new dynamism into these struggles as well. As for the latter, the Hungarian élite understood the popular concept as one that referred to the self-determination (Hungarian: önrendelkezés) of their unitary nation in its unitary state. In their eyes, historical rights, economic necessities, and political circumstances alike supported these claims. Thus, they viewed all attempts to interpret this notion as one corresponding to ethnicity or analogous to autonomy with hostility. Interestingly but not surprisingly, ethnic Hungarians detected an important source of danger in the discourse of the Austrian Imperial Council in relation to the autonomist claims of local nationalities. This was due to the fact that these aimed at annihilating the advantages possessed by the Hungarian nation in the dualist structure and uniting their kin populations in both halves of the Monarchy. ${ }^{33}$ The Hungarian politicians denied even the fact that these ideas would have a support within the targeted populations of the country, who - in their view - were all faithful members of the political nation. ${ }^{34}$

Consequently, any diverging arguments on the concept of self-determination met with great resistance - nonetheless, the representatives of nationalities still succeeded in smuggling them into their speeches. One of the fields to provide a possibility for this were the debates on the idea of the Hungarian suffrage reform. For instance, the representative of the Slovak People's Party, Ferdiš Juriga, saw general suffrage as a democratic norm of new times. However, he also claimed that it does not provide a means to an end in itself; Hungarian legislation must also secure the equality of languages and the right to develop national cultures - in accordance with the democratic right of self-determination. On 4 July 1918, Juriga also argued that it was necessary to erect separate national cadastres for

32 „Nemzetiségi izgatás”, in Pallas Nagy Lexikona, XIII (Budapest: Pallas Irodalmi és Nyomdai Rt., 1896), at: https://mek.oszk.hu/00000/00060/html/074/pc007441.html\#5.

33 The speech of Count Gyula Andrássy (National Party of Constitution). Képviselóházi napló, 1910. XXXVII. kötet. 1917. szeptember 12-deczember 1. 752. országos ülés 1918 november 20án, kedden, 381.

34 The speech of György Platthy (Party of Independence and '48). Képviselőházi napló, 1910. XXXIX. kötet. 1918. április 23 - június 21. 796. országos ülés 1918 június 20-án, csütörtökön, 470. 
the voters of different ethnic groups - on the example of the Austrian system. ${ }^{35}$ One could argue that the Slovak politician used the concept of self-determination to introduce the idea of 'equality of nationalities' in the Austrian sense into the Hungarian context. These propositions were in line with the earlier initiatives of nationalities to transform Hungary into a nationalities state. However, Juriga managed to avoid any territorial connotations in this regard - and thus the commitment of any crimes against the idea of state unity.

It was also in connection with the participation of nationalities in these debates that a new understanding of their position revealed itself in the Parliament. For example, the Transylvanian Saxon representative, Rudolf Brandsch, welcomed the idea of general suffrage as a 'politician representing minorities' (kisebbségeket képviselö politikus) on 2 July 1918. However, he also held interesting views on the position of his respective nationality.

At first sight, this sounds to be an odd statement from the lips of a representative who represents a people which is in a minority in this country. But the punctum saliens in this question is that only that suffrage can be called equal and general which gives rights and possibilities not only to one part of the nation but also to the minorities, and so to the entire nation for emergence. ${ }^{36}$

The statements of the Saxon representative mixed the qualitative with the quantitative understandings of minority. Brandsch saw his ethnic group being in numerical inferiority within the population of Hungary - or, in other words, the Hungarian nation. Yet, the politician also emphasized that the new general suffrage should not advantage one part of the nation - the Hungarian ethnicity dominant in terms of numbers and power - as before, but it should rather be valid for 'minorities' as well. The latter concept was a synonym to nationality - a position defined permanently by not only as a numerical but also a legal-political disadvantage within the existing framework of the Hungarian nation-state; one that would not disappear even with the implementations of suffrage reform. Thus, Brandsch translated and implanted the qualitative meaning of 'minority' into the Hungarian conceptual context.

35 Képviselőházi napló, 1910. XL. kötet. 1918. június 25 - július 19. 804. országos ülés 1918 július 4-én, csütörtökön, 280-281.

36 „Első pillanatra ez a kijelentés különösnek hangzik egy olyan képviselő ajkáról, aki oly népet képvisel, amely kisebbségben van ebben az országban. De a punctum saliens ebben a kérdésben az, hogy csak azt a választójogot lehet egyenlőnek és általánosnak mondani, amely nemcsak a nemzet egy részének, de a kisebbségeknek is, tehát az egész nemzetnek ad jogot és alkalmat az érvényesülésre.” Képviselőházi napló, 1910. XL. kötet. 1918. június 25-július 19. 805. országos ülés 1918. július 2-án, kedden, 123-124. 
The representative of the Romanian National Party, Ştefan Cicio Pop, used the concept in a similar sense but with an additional turn in its utilization. On 6 July 1918, the politician also commented on the debates of suffrage and touched upon the issue of national problems in Hungary.

The provisions of the bill [proposing a regulation of suffrage that is still restricted as opposed to a general one - L. B. B.] are all the more odd and surprising in these times when the worldview is entirely different, when the notion of the right of self-determination of peoples was brought up and those were not the men of the Entente but the men of the Central Powers who set the freedom of language, church, school as a minimum. In this regard, I refer to the so-called Organization Central pour le paix durable [Organization central pour une paix durable, Central Organization for a Durable Peace - L. B. B.], founded in Hagen, 1915 [...] $]^{37}$

Thus, Pop used the international context to make a point concerning the rights of nationalities in Hungary and to argue for their cultural rights in the name of self-determination. He explicitly referred to the Central Organization for a Durable Peace - an international organization in which citizens from neutral countries and those of the Central Powers discussed how to prevent future wars. The politician spent considerable time introducing the resolutions of the 1917 Christiana conference of this organization in relation to the issue of national minorities - quoted by him as minorité nationale in the original French text -, which he summed up as follows in Hungarian: 'So, freedom of nationality, autonomy of the church, freedom of education so that the minority (in archaic Hungarian: minoritás) could erect schools, a university within the state with respect to the laws. ${ }^{38}$

Once again, the representative treated the terms of 'nationality' and 'minority' as equals. Pop also referred to the international example as a source and a standard for the future solution of the nationalities question in Hungary. Similarly to Juriga's comments on self-determination, the Romanian politician avoided to connect this to territorial ideas and rather argued for the rights of minorities - or, in reality, nationalities - in Hungary in a non-territorial sense.

37 „Annál furcsább és meglepőbb a törvényjavaslatnak ez az intézkedése a mai időkben, amikor már egészen más a világnézet, amikor már felvetődött a népek önrendelkezési jogának az eszméje és a nyelv, az egyház, az iskola szabadságát nem az entente emberei, hanem a központi hatalmak emberei mint minimumot állítják fel. Hivatkozom e tekintetben a Hágában 1915-ben megalakult ugynevezett Organisation Central pour le paix durable-ra [...]” Képviselőházi napló, 1910. XL. kötet. 1918. június 25-július 19. 805. országos ülés 1918. július 5-én, pénteken, 304.

38 „Tehát nemzetiségi szabadság, egyházi autonómia, tanszabadságot, hogy iskolákat, egyetemet felállíthat a minoritás az állam kebelén belül a törvények figyelembevétele mellett." Képviselőházi napló, 1910. XL. kötet. 1918. június 25-július 19. 805. országos ülés 1918. július 5-én, pénteken, 304. 
With the war nearing its end, Hungarian politicians also realized that they cannot escape from the complications of the nationality question - especially since they were to find themselves on the side of the defeated in the conflict. On 18 October 1918, it was none other than the infamous Count Albert Apponyi - the mastermind behind the assimilative law of Lex Apponyi in 1907 - who presented his views on the subject. While he belonged to the ranks of the oppositional Party of Independence and '48, he nevertheless stood on the same ground as the government concerning the Hungarian domination of the historical state. Thus, his comments proved to be even more remarkable:

I entirely share the view that on that European or, in general, world peace congress it is not the intervention into the separate internal affairs of certain nations that should be of concern [...] but that certain principles should be placed under international sanctions which protect the rights of the nationality minority [italicized by me - L. B. B.] in all countries, not just in ours but also in Romania, concerning the Hungarians living there $!^{39}$

As such, the speech of the Hungarian oppositional figure contained the same elements as those of the nationality representatives before. All these local actors understood 'minority' as an analogy to 'nationality', what explained Apponyi's use of the term 'nationality minorities'. The Hungarian politician saw this a way of handling the nationalities question. This seemed to be a must so that the integrity of the Hungarian state would be preserved despite its defeat in the war - but, at the same time, Apponyi demanded that these provisions would be generally applicable to international politics. This way, even Hungarian communities of other countries could have had benefits from these.

However, fate had a similar judgement upon these affairs as upon those of Austria - the defeat of the Habsburg Monarchy allowed the secession of its nationalities from the Empire and their unifications within new nation-states. The new system based upon these entities signified a qualitative change in the history of concepts; in the place of the 'nationalities question' of the withering imperial age, the 'minorities question' emerged as a main topic of discussions. The problem of self-determination remained to be connected to these problems. Nonetheless, we argue that all of these concepts already existed simultaneously in the Habsburg Empire of the late First World War era, where the term 'minority' was being handled under the umbrella of the nationalities question and understood as either an analogy or a sub-genre of this topic.

39 „Én teljesen osztozom abban a felfogásban, hogy azon az európai vagy egyáltalán világbékekongresszuson nem egyes nemzetek külön-külön belügyeibe való beavatkozásról lehet szó [...] Hanem igenis arról, hogy nemzetközi szankció alá helyeztessenek bizonyos elvek, amelyek minden országban a nemzetiségi kisebbségnek jogait oltalmazzák nemcsak nálunk, hanem 


\section{Conclusions}

In conclusion, we claim that there is a problem in the approach of legal history in search for the origins of the minority question: namely, that it does not consider the conceptual history and the changes of the actual term itself. Before the First World War, it was not 'minority' but 'nation' (or 'nationality' and their contemporary synonyms) that assumed a central role in the discussions during the long nineteenth century - an issue of utmost importance in the multi-ethnic empires of Central Eastern Europe.

The interwar narrative - with the nation-state becoming the dominant structure of the times - more often than not looked over this historical reality of 'the nationality question' in search of the pre-history of the minority question. This narrative told the story of a five-hundred-year-old legacy of international minority protection. Our critical analysis showed that interwar scholars tried to impose their democratic ideology upon a pre-dominantly monarchic tradition. It is also of great importance that their analysis was based on the viewpoint of the nation-state; they mixed the contemporary 'minority question' with the 'nationality question' of the earlier imperial times that led to an anachronistic understanding of these issues.

Nonetheless, the analysis of the Habsburg context sheds light on the developments in this regard. While it is clear that 'minority' was predominantly a quantitative notion in both the Austrian and the Hungarian political and legal spheres, it nevertheless had some connotations to the national question in these highly diverse political entities. Austria lacked nationally defined territorial structures, and the Hungarian legal-political tradition rather used the terms 'nation' and 'nationality'. Thus, a qualitative understanding of a 'minority' as a legal entity, i.e. a (national) group to be invested with rights, did not appear before the First World War.

The Great War initiated important changes on both the international and the imperial scene, these being connected to each other. The transformation or the destruction of the imperial framework necessitated the conceptualization of new national territories in its ethnically diverse lands, which was captured with the notions of 'majority' and 'minority'. The newly emerged language of 'minority protection' functioned as a 'third idiom' - a new, unfamiliar language that is accessible to both sides yet not owned by any of them $-^{40}$ to which politicians and

Romániában is az ott lakó magyarságét!” Képviselőházi napló, 1910. XLI. kötet. 1918. július 24-november 16. 825. országos ülés 1918. október 18-án, pénteken, 322.

40 Martin Fuchs defines 'third idiom' as 'a mode of translation that tries to introduce an idiom which transcends the limitations of two conflicting positions, discourses or frames of reference'. He emphasizes that 'The idea of a third idiom is to overrule and replace the prevalent dominant language or ideology, using as an alternative platform not one's own local idiom but an idiom that transcends the two conflicted sides or discourses and provides space for both' (Fuchs 2009: 31, 38). 
legal scholars had to translate their views on the idea of national in order to gain the ears of their fellow citizens belonging to other identity groups.

Thus, the concept of minority appeared in the framework of the 'nationalities question' as its sub-genre in the discussions of both the Austrian Reichsrat and the Hungarian Parliament due to transnational transfers from other contexts. The key figures arguing for 'minority rights' inserted these into the framework of their old arguments for imperial reform - whether the sources of these were to be found in the establishment of new states or in the debates of international organizations. In other words, 1918 saw the first appearances of the new concept of minority - a legal notion designating a national group as a whole that was in numerical and legal disadvantage as opposed to the nations that were expected to constitute new states or sub-states in the Habsburg lands.

It was this change that made its way into the peace-making processes after the First World War, most notably in the form of the so-called 'Minority Treaties' and the Covenant of the League of Nations. Both the new international order and the nation-states replaced the old empires and their ethnic diversity with their legal and political focus on one dominant community. 'Minorities' were invested with special rights within these new entities. Thus, whereas it is anachronistic to talk about 'minority rights' in the period before the late First World War era, it is also clear that the treaties of the Paris Peace Conference contained a notion that appeared already before the establishment of the nationstate system. In fact, the birth of the 'national minority' concept was intertwined with the preceding imperial framework and its most important problem, that of the 'nationalities question'.

Our paper sprang from the foundational claim of the 'Begriffsgeschichte' that a conceptual change signals a change in how people experienced reality (Koselleck 1972: XIII-XXVII; Case 2018: 37). Thus, a conceptual change indicates a change in the paradigm. We believe that the anachronistic usage of historical terms is unavoidable, yet anachronistic terms tell more about an author's intention than about the past. Even today, in the heat of an argument, the history of the minority concept is often neglected. Consequently, to reflect on these intensions when conceptualizing the past is an important task of the historian. 


\section{References}

ADLGASSER, Franz. 2014. Die Mitglieder der Österreichischen Zentralparlamente 1848-1918. Konstituierender Reichstag 1848-1849. Reichsrat 1861-1918. Ein Biographisches Lexikon, vol. 1. Studien zur Geschichte der Österreichisch-Ungarischen Monarchie 33. Wien: Österreichische Akademie der Wissenschaften.

BALOGH, Arthur. 1928. A kisebbségek nemzetközi védelme. Berlin: Ludwig Veggenreiter Verlag. Magyar osztály.

1940. Kisebbség-nemzetiség. Magyar Kisebbség 19(7-8): 158-163.

BAUER, Otto. 1907. Die Nationalitätenfrage und die Sozialdemokratie. Wien: Verlag der Wiener Volksbuchhandlung Ignaz Brand.

BINDER, Harald. 2006. “Galizische Autonomie.” Ein Streitbarer Begriff und Seine Karriere. In: Fasora, Lukás-Hanus, Jirí-Malír, Jirí (eds), Moravské Vyrovnání z Roku 1905 / Der Mährische Ausgleich von 1905. Brno: Matice moravská pro Výzkumné středisko pro dějiny střední Evropy.

BOTTOMORE, Tom. 1993 [1964]. Élites and Society. London-New York: Routledge.

B[RÓDY], Zs[igmond]. 1869. [Review of Österreich und die Bürgschaften seines Bestandes]. Pesti Napló 20(282): 1-2.

BURKE, Peter. 2007. Cultures of Translation in Early Modern Europe. In: Burke, Peter-Hsia, R. Po-Chia (eds), Cultural Translation in Early Modern Europe. Cambridge: Cambridge University Press.

CASE, Holly. 2018. The Age of Questions. Princeton: Princeton University Press. CHERNEV, Borislav. 2011. The Brest-Litovsk Moment: Self-Determination Discourse in Eastern Europe before Wilsonianism. Diplomacy \& Statecraft 22(3): 369-387.

CZUCZOR, Gergely-FOGARASI, János. 1865. A magyar nyelv szótára. Harmadik kötet. Pest: Emich Gusztáv Magyar Akadémiai Nyomdász.

DEMETER, M. Attila. 2016. Politikai nemzet versus nemzetiség-1848, 1861, 1868. Nemzet, faj, kultúra a hosszú 19. században Magyarországon és Európában. In: Hörcher, Ferenc-Lajtai, Mátyás-Mester, Béla (eds), Magyar történelmi emlékek. Értekezések. Tanulmányok a nacionalizmus kultúrtörténetéből 2. Budapest: MTA, 238-260.

DUKA ZÓLYOMI, Norbert. 1939. Az európai nemzetiségek önkormányzatai a világháború előtt. Magyar Kisebbség 13(18): 309-322.

DUPARC, Fouques. 1922. La Protection des Minorités de Race, de Langue et de Religion. Paris: Dalloz.

EÖTVÖS, József. 1840. A „,zsidók” emancipátiója. Budapesti Szemle. 2: 110-156. 1850. Über die Gleichberechtigung der Nationalitäten in Österreich. Pest: Hartleben Verlag. 
FENYŐ, István. 2007. Eötvös és Tocqueville. Aetas 22(1): 127-134.

FISCHHOF, Adolf. 1869. Oesterreich und die Bürgschaften Seines Bestandes. Wien: Wallishausser'sche Buchhandlung.

FUCHS, Martin. 2009. Reaching Out; Or, Nobody Exists in One Context Only. Society as Translation. Translation Studies 2(1): 21-40.

GÁNGÓ, Gábor. 1998. Eötvös József Ausztria nemzetiségeinek egyenjogúsításáról címú röpirata és 1848-49 nemzetiségi mozgalmainak néhány aspektusa. Századok 132(2): 371-396.

GLEASON, Philip. 1991. Minorities (Almost) All: The Minority Concept in American Social Thought. America Quarterly 43: 392-424.

GYURGYÁK, János. 2007. Ezzé lett magyar hazátok. A magyar nemzeteszme és nacionalizmus története [This Is What Your Magyar Country Has Become. The History of Hungarian National Identity and Nationalism]. Budapest: Osiris.

JÁSZI, Oszkár. 1912. A nemzeti államok kialakulása és a nemzetiségi kérdés. Budapest: Grill Károly.

JELLINEK, Georg. 1898. Das Recht der Minoritäten. Wien: Alfred Hölder.

JUDSON, Pieter M. 2016. The Habsburg Empire. A New History. Cambridge, Massachusetts-London, England: The Belknap Press of Harvard University Press.

KANN, Robert A. 1950. The Multinational Empire. Nationalism and National Reform in the Habsburg Monarchy 1848-1918. New York: Columbia University Press.

KNAPP, Vincent J. 1981. Austrian Social Democracy, 1889-1914. Rowman \& Littlefield.

KÓNYI, Manó. 1889. Deák Ferencz beszédei. Ötödik kötet (1867-1868). Budapest: Franklin Társulat.

KOSELLECK, Reinhart. 1972. Einleitung. In: Koselleck, Reinhart-Conze, WernerBrunner, Otto (eds), Geschichtliche Grundbegriffe. Historisches Lexikon zur politisch-souialen Sprache in Deutschland. vol. 1. Stuttgart: Klett-Kotta. XIIIXXVII.

MACARTNEY, Carlile Aylmer. 1934. National States and National Minorities. London: Milford.

MAGOCSI, Paul Robert. 2010. The History of Ukraine: The Land and Its Peoples. Toronto-Buffalo-London: University of Toronto Press.

MANELA, Erez. 2009. The Wilsonian Moment. Oxford Studies in International History. Oxford University Press.

MIKÓ, Imre. 1932. Az erdélyi falu és a nemzetiségi kérdés. Kolozsvár: Erdélyi fiatalok [http://adatbank.transindex.ro/inchtm.php?akod=1064, 10.12.2019]. 1944. Nemzetiségi jog és nemzetiségi politika. Tanulmány a magyar közjog és politikai történet köréból. Kolozsvár: Minerva. 
RASCHHOFER, Hermann. 1931. Hauptprobleme des Nationalitätenrechts. Stuttgat: Verlag von Ferdinand Enke.

REIFOWITZ, Ian. 2001. Threads Intertwined: German National Egoism and Liberalism in Adolf Fischhof's Vision for Austria. Nationalities Papers 29(34): 441-458.

RUMPLER, Helmut. 2016. Die Todeskrise Cisleitheniens 1911-1918. Vom Primat der Innenpolitik zum Primat der Kriegsentscheidung. In: Rumpler, Helmut (ed.), Die Habsburgermonarchie 1848-1918, XI., Vol. 1. Die Habsburgermonarchie und der Erste Weltkrieg. Verlag der Österreischischen Akademie der Wissenschaften. 1165-1256.

SEIPEL, Ignaz. 1925. Die geistigen Grundlagen der Minderheitenfrage. Wien.

SKINNER, Quentin. 1969. Meaning and Understanding in the History of Ideas. History and Theory 8(1): 3-53.

STOURZH, Gerald. 1985. Die Gleichberichtigung der Nationalitäten in der Verfassung und Verwaltung Österreichs. 1848-1918. Österreichische Akademie der Wissenschaften.

SZABÓ, Dániel. 2016. Die Agonie des historischen Ungarn. Die Einheitliche und Unteilbare Ungarische Nation im Weltkrieg. In: Rumpler, Helmut (ed.), Die Habsburgermonarchie 1848-1918. Vol. XI/1. Die Habsburgermonarchie und der Erste Weltkrieg. Verlag der Österreischischen Akademie der Wissenschaften. 679-710.

SZEREMLEI, Samu. 1867. Magyarország krónikája az 1848. és 1849. évi forradalom idejéról. 1. Pest: Emich Gusztáv.

SZOKOLY Viktor (ed.). 1867. Mészáros Lázár emlékiratai. 1. kötet. In: Pest: Ráth Mór.

TARR, Zoltan. 1999. Ethnicity, Nationality, and Nationalism in Early AustrianHungarian Social Science. In: Marcus, Judith (ed.), Surviving the Twentieth Century: Social Philosophy from the Frankfurt School to the Columbia Faculty. New Jersey: Transaction Publishers.

UNTERBERGER, Betty Miller. 1989. The United States, Revolutionary Russia, and the Rise of Czechoslovakia. Chapel Hill-London: The University of North Carolina Press.

VIEFHAUS, Erwin. 1960. Die Minderheitenfrage und die Entstehung der Minderheitenschutzverträge auf der Pariser Friedenskonferenz 1919: eine Studie zur Geschichte des Nationalitätenproblems im 19. und 20. Jahrhundert. Würzburg: Holzner. 